OPEN ACCESS

Edited by: Julie Anne Maupin-Furlow, University of Florida, United States

Reviewed by:

Haruyuki Atomi,

Kyoto University, Japan

Volker F. Wendisch,

Bielefeld University, Germany

*Correspondence:

Bettina Siebers

bettina.siebers@uni-due.de

Specialty section:

This article was submitted to Microbial Physiology and Metabolism,

a section of the journal

Frontiers in Microbiology

Received: 08 January 2019

Accepted: 26 March 2019

Published: 12 April 2019

Citation:

Haferkamp P, Tjaden B, Shen L, Bräsen $C$, Kouril $T$ and Siebers $B$

(2019) The Carbon Switch

at the Level of Pyruvate

and Phosphoenolpyruvate

in Sulfolobus solfataricus P2.

Front. Microbiol. 10:757.

doi: 10.3389/fmicb.2019.00757

\section{The Carbon Switch at the Level of Pyruvate and Phosphoenolpyruvate in Sulfolobus solfataricus P2}

\author{
Patrick Haferkamp ${ }^{1}$, Britta Tjaden', Lu Shen', Christopher Bräsen', Theresa Kouril1,2 \\ and Bettina Siebers ${ }^{1 *}$
}

${ }^{1}$ Molecular Enzyme Technology and Biochemistry, Biofilm Centre, Centre for Water and Environmental Research, Faculty of Chemistry, University of Duisburg-Essen, Essen, Germany, ${ }^{2}$ Department of Biochemistry, University of Stellenbosch,

Stellenbosch, South Africa

Sulfolobus solfataricus P2 grows on different carbohydrates as well as alcohols, peptides and amino acids. Carbohydrates such as D-glucose or D-galactose are degraded via the modified, branched Entner-Doudoroff (ED) pathway whereas growth on peptides requires the Embden-Meyerhof-Parnas (EMP) pathway for gluconeogenesis. As for most hyperthermophilic Archaea an important control point is established at the level of triosephophate conversion, however, the regulation at the level of pyruvate/phosphoenolpyruvate conversion was not tackled so far. Here we describe the cloning, expression, purification and characterization of the pyruvate kinase (PK, SSO0981) and the phosphoenolpyruvate synthetase (PEPS, SSO0883) of Sul. solfataricus. The PK showed only catabolic activity [catalytic efficiency (PEP): $627.95 \mathrm{mM}^{-1} \mathrm{~s}^{-1}, 70^{\circ} \mathrm{C}$ ] with phosphoenolpyruvate as substrate and ADP as phosphate acceptor and was allosterically inhibited by ATP and isocitrate $\left(K_{i}\right.$ $0.8 \mathrm{mM})$. The PEPS was reversible, however, exhibited preferred activity in the gluconeogenic direction [catalytic efficiency (pyruvate): $1.04 \mathrm{mM}^{-1} \mathrm{~s}^{-1}, 70^{\circ} \mathrm{C}$ ] and showed some inhibition by AMP and $\alpha$-ketoglutarate. The gene SSO2829 annotated as PEPS/pyruvate:phosphate dikinase (PPDK) revealed neither PEPS nor PPDK activity. Our studies suggest that the energy charge of the cell as well as the availability of building blocks in the citric acid cycle and the carbon/nitrogen balance plays a major role in the Sul. solfataricus carbon switch. The comparison of regulatory features of wellstudied hyperthermophilic Archaea reveals a close link and sophisticated coordination between the respective sugar kinases and the kinetic and regulatory properties of the enzymes at the level of PEP-pyruvate conversion.

Keywords: Archaea, (hyper)thermoacidophile, Sulfolobus solfataricus, pyruvate kinase, phosphoenolpyruvate synthetase, carbon switch

\section{INTRODUCTION}

Archaea resemble in their metabolic diversity and complexity bacteria and primitive eukaryotes. However, their metabolism is characterized by many new, unusual pathways and enzymes (Sato and Atomi, 2011; Bräsen et al., 2014; Nelson-Sathi et al., 2015; Wolf et al., 2016). Even the generic pathways of sugar degradation, such as the EMP and the ED pathway, have 
modifications as compared to the classical pathways (for reviews see Ronimus and Morgan, 2003; Verhees et al., 2003; Siebers and Schönheit, 2005; Bräsen et al., 2014). Most catalyzed reactions as well as the intermediates of the modified archaeal pathways resemble the classical glycolytic pathways in bacteria and eukaryotes. However, many of the utilized archaeal enzymes share no homology with their bacterial and eukaryotic counterparts but are members of different 'new' enzyme families [e.g., ADP/ATP-dependent hexo(gluco)kinases and ADP/ATPdependent PFK of the ribokinase enzyme family; archaeal type class I fructose-1,6-bisphosphate aldolase of the DhnA family] (for review see Bräsen et al., 2014). This 'acquirement' of new catalysts is often accompanied by new regulatory properties. For example all archaeal sugar kinases characterized so far exhibit no allosteric properties and thus give rise to novel control points in the central metabolic pathways. These modified archaeal pathways therefore offer great potential for metabolic engineering and synthetic biology by the combination with classical bacterial and eukaryotic features.

The thermoacidophilic crenarchaeon Sulfolobus solfataricus (strain P2) grows optimally at $80^{\circ} \mathrm{C}\left(60-92^{\circ} \mathrm{C}\right)$ and $\mathrm{pH} 2-4$ (Zillig et al., 1980) and is able to maintain an intracellular $\mathrm{pH}$ at around 6.5 (Moll and Schäfer, 1988). The organism uses a modification of the classical ED pathway for glucose breakdown and the reverse EMP pathway for gluconeogenesis as reported earlier (Lamble et al., 2003; Ahmed et al., 2005; Bräsen et al., 2014). The branched ED pathway is promiscuous for D-glucose and D-galactose degradation; 2-keto-3-deoxygluconate (KDG) and 2-keto-3-deoxy-6-phoshogluconate (KDPG) are the characteristic intermediates of the non-phosphorylative ED (npED) and spED pathway, respectively. After aldolase cleavage pyruvate and glyceraldehyde 3-phosphate (GAP, spED) or 2-phosphoglycerate (2PG, npED) are formed and both are channeled into the lower EMP pathway forming a second molecule of pyruvate (Ahmed et al., 2005). From a genetic approach in Sul. solfataricus (KDG kinase knock-out) combined with metabolomics and enzymatic studies there is evidence that the spED pathway plays a major anabolic role for

\footnotetext{
Abbreviations:1,3BPG, 1,3-bisphosphoglycerate; 2PG, 2-phoshoglycerate; 3-PG, 3-phohoglycerate; ADP, adenosine diphosphate; AMP, adenosine monophosphate; AOR, glyceraldehyde:ferredoxin oxidoreductase; ATP, adenosine triphosphate; CTP, cytidine triphosphate; DHAP, Dihydroxyacetone phosphate; ED, Entner-Doudoroff; EMP, Embden-Meyerhof-Parnas; ENO, Enolase; F1,6BP, Fructose 1,6-bisphophate; F2,6BP, Fructose 2,6-bisphophate; F6P, fructose 6-phosphate; FBPA/ase, fructose 1,6-bisphosphate aldolase/phosphatase; Fructose 1,6- $\mathrm{P}_{2}$, fructose 1,6-bisphosphate; G1P, glucose 1-phosphate; G6P, glucose 6-phosphate; GAD, gluconate dehydratase; GAP, glyceraldehyde 3-phosphate; GAPDH, glyceraldehyde-3-phosphate dehydrogenase; GAPN, nonphosphorylating GAPDH; GDH, glucose dehydrogenase; GDP, guanosine diphosphate; GK, glycerate kinase; GTP, guanosine triphosphate; HK, hexokinase; $\mathrm{KD}(\mathrm{P}) \mathrm{GA}$, 2-keto-3-deoxy-(6-phospho)gluconate aldolase; KDG, 2-keto-3-deoxygluconate; KDGK, 2-keto-3-deoxygluconate kinase; KDPG, 2-keto-3-deoxy-6-phoshogluconate; LDH, lactate dehydrogenase; npED, non-phosphorylative ED; ORF, open reading frame; PCK, PEPcarboxykinase; PEP, phosphoenolpyruvate; PEPS, phosphoenolpyruvate synthetase; PFK, Phosphofructokinase; PGAM, phosphoglycerate mutase; PGI, phosphoglucose/phosphomannose isomerase; PGK, phosphoglycerate kinase; PGM, phosphoglucomutase/phosphomannomutase; $\mathrm{P}_{\mathrm{i}}$, inorganic phophate; $\mathrm{PK}$, pyruvate kinase; $\mathrm{PPDK}$, pyruvate:phosphate dikinase; $\mathrm{PP}_{\mathrm{i}}$, pyrophosphate; $\mathrm{RT}$, room temperature; spED, semi-phosphorylative ED; TIM, triosephosphate isomerase; UTP, uridine triphosphate.
}

the generation of hexose phosphates under glycolytic growth conditions (Kouril et al., 2013b). In addition, the upper catabolic part of the EMP pathway is active (from glucose to fructose 6-phosphate) and provides hexose phosphates via hexokinase and phosphoglucose isomerase in Sulfolobus spp. (Nishimasu et al., 2006). Fructose-6-phosphate constitutes the precursor for pentose generation via the reverse ribulose monophosphate pathway (Orita et al., 2006), and G6P is the building block for glycogen and trehalose formation in Sulfolobus (König et al., 1982; Maruta et al., 1996; Kouril et al., 2008; Zaparty and Siebers, 2011). For a functional glycolysis via the EMP pathway only the PFK seems to be missing and no functional, catabolic fructose-1,6-bisphosphate aldolase (FBPA) was identified so far. Pyruvate as central metabolite is channeled into the citric acid cycle and is completely oxidized to $\mathrm{CO}_{2}$. Reducing equivalents are transferred into the branched respiratory chain with oxygen as terminal acceptor for energy conversion via electron transfer phosphorylation. In addition, Sul. solfataricus grows on various non-saccharolytic substrates such as peptides, amino acids or alcohols and the reversed EMP pathway is used for gluconeogenesis.

Thus, like in other organism pyruvate is one central hub in the metabolism of Sul. solfataricus that channels carbon into different anabolic and catabolic pathways implying an important metabolic control point. In the lower common part of the classical EMP pathway in Bacteria, the conversion between phosphoenolpyruvate (PEP) and pyruvate via the antagonistic enzyme couple, catabolic PK and anabolic PEPS, serves as a switch between glycolysis and gluconeogenesis. In few species in addition a PPDK is found, which catalyzes the reversible conversion of PEP and pyruvate (Evans and Wood, 1968) and in contrast to PEPS, requires $P_{i}$ in the anabolic and $\mathrm{PP}_{\mathrm{i}}$ in the catabolic direction for activity (see Equations 1-3, $\Delta \mathrm{G}^{\circ}$ '-values were calculated via eQuilibrator ${ }^{1}$, Flamholz et al., 2012).

(1) Pyruvate kinase (PK, EC 2.7.1.40) $\mathrm{PEP}+\mathrm{ADP} \rightarrow$ Pyruvate $+\mathrm{ATP}\left(\Delta \mathrm{G}^{\circ}=-27.7 \mathrm{~kJ} / \mathrm{mol}\right.$, $-32 \mathrm{~kJ} / \mathrm{mol}$ at $75^{\circ} \mathrm{C}$ )

(2) Phosphoenolpyruvate synthetase (PEPS, EC 2.7.9.2) Pyruvate + ATP $+\mathrm{H}_{2} \mathrm{O} \rightarrow \mathrm{PEP}+\mathrm{AMP}+\mathrm{P}_{\mathrm{i}}$ $\left(\Delta \mathrm{G}^{\circ}=3.8 \mathrm{~kJ} / \mathrm{mol}, 4.5 \mathrm{~kJ} / \mathrm{mol}\right.$ at $\left.75^{\circ} \mathrm{C}\right)$

(3) Pyruvate:phosphate dikinase (PPDK, EC 2.7.9.1) Pyruvate $+\mathrm{ATP}+\mathrm{P}_{\mathrm{i}} \leftrightarrow \mathrm{PEP}+\mathrm{AMP}+\mathrm{PP}_{\mathrm{i}}$ $\left(\Delta \mathrm{G}^{\circ}=19.6 \mathrm{~kJ} / \mathrm{mol}, 23 \mathrm{~kJ} / \mathrm{mol}\right.$ at $\left.75^{\circ} \mathrm{C}\right)$

Till now, little is known about the PEP-pyruvate conversion and its regulatory function for the glycolytic/gluconeogenic switch in members of the Sulfolobales. In order to unravel the regulatory properties, the genes annotated as PK (SSO0981), PEPS (SSO0883) and putative PEPS or PPDK (SSO2820) of Sul. solfataricus P2 were cloned, recombinantly expressed, purified and characterized. Here we report the regulatory properties at the level of $\mathrm{PEP} /$ pyruvate conversion and compare the findings to other well characterized hyperthermophilic Archaea.

\footnotetext{
${ }^{1}$ http://equilibrator.weizmann.ac.il/
} 


\section{MATERIALS AND METHODS}

\section{Cloning and Expression of the PEPS, the PK and the Putative PEPS/PPDK of Sulfolobus solfataricus in Escherichia coli}

The genes encoding the PK (SSO0981) and the putative PEPS/PPDK (SSO2820) were amplified by PCR mutagenesis using the KOD HiFi DNA Polymerase (Novagen). For the PCR reaction the following primer sets were used $\left(55^{\circ} \mathrm{C}\right.$ annealing temperature).

\section{Forward SSO0981_BspHI ggggctcgagtcatgagaaagactaaaatag $\operatorname{ttgc}$ \\ Reverse SSO0981_XbaI \\ Forward SSO2820_NdeI \\ ggcggtctagatcatttctttgttgttctag \\ Reverse SSO2820_BamHI \\ gggggaattcatatgaactatacatacttac \\ ggcggggatcctcaaaattcgggatacaatcg}

After digestion with BspHI and XbaI for SSO0981 as well as NdeI and BamHI for SSO2820 the constructs were ligated into pET324 (SSO0981) and pET11c (SSO2820), respectively. The gene encoding PEPS (SSO0883), was synthesized (codon optimized for expression in Escherichia coli; for sequence see Supplementary Material) and cloned into pET11c by Eurofins MWG (Ebersberg, Germany).

The resulting constructs (PK_pET324, SSO2820_pET11c, PEPS_pET11c) were transformed into competent E. coli Rosetta (DE3) pRIL cells (Novagen). The cells were cultivated in a $5 \mathrm{~L}$ fermenter (Minifors, Infors HT) with $4.5 \mathrm{~L}$ of LB-medium, $100 \mu \mathrm{g} / \mathrm{ml}$ ampicilin, $34 \mu \mathrm{g} / \mathrm{ml}$ chloramphenicol, and $25 \mu \mathrm{L} / \mathrm{L}$ (v/v) of antifoam 204 (Sigma). The fermenter was inoculated with $2 \%(\mathrm{v} / \mathrm{v})$ of a pre-culture of the respective expression strain and fermentation was performed at $37^{\circ} \mathrm{C}, 750 \mathrm{rpm}$ and aeration ( 1 bar). Gene expression was induced at $\mathrm{OD}_{600}$ of $0.5-0.8$ by adding isopropyl- $\beta$-D-thiogalacto-pyranoside to a final concentration of $1 \mathrm{mM}$. The cells were grown until the stationary phase was reached and cells were harvested by centrifugation $\left(5465 \times \mathrm{g}, 20 \mathrm{~min}, 4^{\circ} \mathrm{C}\right)$ and stored at $-80^{\circ} \mathrm{C}$ ( $\sim 10$ g wet weight).

\section{Purification of the Recombinant Proteins}

For the purification of PK (SSO0981) and the putative PEPS/PPDK (SSO2820) cells were re-suspended in $30 \mathrm{~mL}$ $100 \mathrm{mM}$ HEPES/KOH, pH 7 [room temperature (RT)] [3 mL buffer/g cells (wet weight)]. Cell disruption was performed by sonification (ultrasound processor UP 200s, Hielscher Ultrasonics $\mathrm{GmbH}$ ) at an intensity of $50 \%$ for $4 \times 5 \mathrm{~min}$ interrupted by intervals of $30 \mathrm{~s}$ on ice. Cell debris and unbroken cells were removed by centrifugation $\left(21,000 \times g, 1 \mathrm{~h}, 4^{\circ} \mathrm{C}\right)$. The resulting crude extract was diluted $1: 1$ with $100 \mathrm{mM}$ $\mathrm{HEPES} / \mathrm{KOH}, \mathrm{pH} 7$ (RT). Recombinant Sul. solfataricus proteins were enriched via heat precipitation for $20 \mathrm{~min}$ at $80^{\circ} \mathrm{C}$, followed by centrifugation $\left(21,000 \times g, 1 \mathrm{~h}, 4^{\circ} \mathrm{C}\right)$. For the PEPS/PPDK the protein fraction was directly used for enzymatic analysis, whereas the PK was further purified.
For ion exchange chromatography the PK protein solution was dialyzed against $20 \mathrm{mM}$ HEPES/KOH (pH 7, RT). Ion chromatography was performed using a continuous bed ion exchange column (12 mL, Q-Sepharose Fast Flow, GE Healthcare). After equilibration of the column the protein sample was applied and proteins were eluted via a continuous gradient of $0-1 \mathrm{M} \mathrm{NaCl}$ in $20 \mathrm{mM}$ HEPES/KOH, pH 7 (RT) (336 $\mathrm{mL}$, flow rate: $5 \mathrm{~mL} / \mathrm{min}$ ). Fractions containing the target enzymes were pooled and dialyzed against $5 \mathrm{~L}$ of $20 \mathrm{mM}$ $\mathrm{HEPES} / \mathrm{KOH}, \mathrm{pH} 7$ (RT) for $2 \mathrm{~h}$. The sample volume was reduced to $4.5 \mathrm{~mL}$ via centrifugation $\left(3000 \times g, 4^{\circ} \mathrm{C}\right)$ using Vivaspin 20 diafiltration cups (10,000 MWCO PES, Sartorius Stedium Biotech). Gel filtration was performed applying the protein samples to HiLoad 26/60 Superdex ${ }^{\mathrm{TM}} 200$ prep grade (GE Healthcare) pre-equilibrated in running buffer $[50 \mathrm{mM}$ HEPES/KOH, $300 \mathrm{mM} \mathrm{KCl,} \mathrm{pH} 7$ (RT)]. Protein separation was performed at a flow rate of $2 \mathrm{~mL} / \mathrm{min}$. Fractions containing the target protein were pooled and the protein sample was stored at $4^{\circ} \mathrm{C}$.

For the purification of PEPS (SSO0883) cells were resuspended in $100 \mathrm{mM}$ Tris $/ \mathrm{HCl} \mathrm{pH} 7\left(70^{\circ} \mathrm{C}\right), 20 \mathrm{mM}$ $\beta$-mercaptoethanol and $1 \mathrm{mM} \mathrm{MgCl}_{2}$. After sonification [ $3 \times 5 \mathrm{~min}$, (intensity of $60 \%)]$ and centrifugation $(21,000 \times g$, $\left.30 \mathrm{~min}, 4^{\circ} \mathrm{C}\right)$ the heat precipitation $\left(20 \mathrm{~min}\right.$ at $\left.75^{\circ} \mathrm{C}\right)$ was performed without further dilution followed by centrifugation $\left(21,000 \times \mathrm{g}, 30 \mathrm{~min}, 4^{\circ} \mathrm{C}\right)$. Due to the instability of the PEPS no further purification steps were performed.

\section{Enzyme Assays Pyruvate Kinase}

The assay was performed continuously at 50,60 , and $65^{\circ} \mathrm{C}$ in the presence of $100 \mathrm{mM} \mathrm{HEPES} / \mathrm{KOH}$ ( $\mathrm{pH} 6.5$ at the respective temperature), $0.2 \mathrm{mM} \mathrm{NADH}, 4 \mathrm{U}$ of lactate dehydrogenase (LDH, rabbit muscle; Sigma), 0-5 mM PEP, $5 \mathrm{mM}$ ADP, $0.75-2 \mathrm{mg} / \mathrm{mL}$ of protein, and $10 \mathrm{mM} \mathrm{MgCl}_{2}$ (total volume of $500 \mu \mathrm{L})$. Enzyme activity was determined by monitoring the decrease in absorption at $340 \mathrm{~nm}$. Reactions were started by adding the substrate PEP.

Pyruvate kinase activity at $70^{\circ} \mathrm{C}$ and $80^{\circ} \mathrm{C}$ was determined using a discontinuous enzyme assay, performed in 0.1 M HEPES ( $\mathrm{pH} 6.5$ at 70 or $80^{\circ} \mathrm{C}$ ) with $0.75-2 \mu \mathrm{g}$ of protein in presence of $10 \mathrm{mM} \mathrm{MgCl}_{2}$ in a total volume of $120 \mu \mathrm{L}$. Reactions were started by the addition of PEP and samples were removed after 0 , $1,2,3$, and $4 \mathrm{~min}$ and stored on ice. The tested range of substrate and co-substrate concentrations were $0.01 \mathrm{mM}-10 \mathrm{mM}$ for PEP and $0.02 \mathrm{mM}-5 \mathrm{mM}$ for ADP. Formed pyruvate was detected in an indicator reaction at $37^{\circ} \mathrm{C}$ in $0.1 \mathrm{M} \mathrm{HEPES} / \mathrm{KOH}(\mathrm{pH} 7$, $\mathrm{RT}$ ) containing $0.5 \mathrm{mM} \mathrm{NADH}$ and $4 \mathrm{U} \mathrm{LDH}$ (total volume $500 \mu \mathrm{L}, 340 \mathrm{~nm})$.

Assays in presence of effectors were performed in a continuous assay system $(500 \mu \mathrm{L}$ total volume $)$ at $60^{\circ} \mathrm{C}$ under half-saturating substrate conditions for PK $(0.03 \mathrm{mM}$ $\mathrm{PEP}$ ) in the presence of $2.3 \mu \mathrm{g}$ protein, $0.2 \mathrm{mM} \mathrm{NADH}, 4 \mathrm{U}$ $\mathrm{LDH}$ (rabbit-muscle, Sigma-Aldrich), $2 \mathrm{mM} \mathrm{ADP}$ and $10 \mathrm{mM}$ $\mathrm{MgCl}_{2}$. Following effectors were used in final concentrations of $1 \mathrm{mM}$ : fructose 6-phosphate, fructose 1,6-bisphosphate, glucose 
6-phosphate, glucose 1-phosphate, trehalose 6-phosphate, fructose 1-phosphate, ribose 1-phosphate, UDP-glucose, 2-keto3-deoxy-6-phospho-D-gluconate, 3-phosphoglycerate, 2-phosphoglycerate, dihydroxyacetone phosphate, glyceraldehyde 3-phosphate, citrate, malate, oxaloacetate, $\alpha$-ketoglutarate, succinate, fumarate, 2-oxo-glutamate, isocitrate, $\mathrm{KP}_{\mathrm{i}}, \mathrm{PP}_{\mathrm{i}}, \mathrm{AMP}$, ATP, UTP, CTP. More detailed analyses were performed in presence of ATP and isocitrate by varying the concentrations between 0.1 and $6 \mathrm{mM}$.

\section{Phosphoenolpyruvate Synthetase}

Phosphoenolpyruvate synthetase activity in both the anabolic and catalytic direction was determined at $70^{\circ} \mathrm{C}$ using a discontinuous assay according to Eyzaguirre et al. (1982). The standard assay (total volume $25-50 \mu \mathrm{L}$ ) was performed in $100 \mathrm{mM}$ Tris $/ \mathrm{HCl}$, $\mathrm{pH} 7.0\left(\right.$ at $70^{\circ} \mathrm{C}$ ), in the presence of $30 \mathrm{mM} \beta$-mercaptoethanol, $10 \mathrm{mM} \mathrm{MgCl}_{2}$ and $20 \mu \mathrm{g}$ of purified enzyme.

For the anabolic direction, $0.1-10 \mathrm{mM}$ pyruvate and 0.1-10 mM ATP were used as substrate and cosubstrate, respectively. The reaction was stopped at $0,2,4,6,8$, and $10 \mathrm{~min}$ by transferring the samples on ice. The formed PEP was determined at RT after $60-300 \mathrm{~s}$ in $0.5 \mathrm{~mL} 100 \mathrm{mM}$ Tris/HCl (pH 7.0), $20 \mathrm{mM} \mathrm{MgCl}_{2}, 1 \mathrm{mM} \mathrm{ADP}$ and $0.8 \mathrm{mM}$ $\mathrm{NADH}$ by calculating the decrease in absorption at $365 \mathrm{~nm}$ $\left(\varepsilon_{25^{\circ} \mathrm{C}}=3,4 \mathrm{mM}^{-1} \mathrm{~cm}^{-1}\right)$ using $10 \mathrm{U} \mathrm{LDH} \mathrm{(rabbit} \mathrm{muscle)}$ and $5 \mathrm{U}$ PK (rabbit muscle) as auxiliary enzymes. To clarify whether AMP/Pi or ADP is produced in the anabolic direction, the samples obtained at different time points [using $6 \mathrm{mM}$ pyruvate and $10 \mathrm{mM}$ ATP as (co)substrates] were transferred to centrifugal concentrators (VIVASPIN 500, Sartorius) to remove the protein. The concentration of PEP in the obtained flow through was determined as described above. In addition, the assay was performed in absence of ADP or with addition of $1 \mathrm{mM}$ ATP and $5 \mathrm{U}$ myokinase (rabbit muscle) to differentiate between the formation of ADP and AMP, respectively.

For the catabolic direction $6 \mathrm{mM} \mathrm{PEP,} 10 \mathrm{mM} \mathrm{K}_{2} \mathrm{HPO}_{4}$ and $10 \mathrm{mM}$ ADP or AMP were used as substrates and the formed pyruvate was determined as described for PEP detection, however, in absence of the $\mathrm{MgCl}_{2}, \mathrm{ADP}$ and PK. To analyze the regulatory properties of PEPS, various metabolites ( $\alpha$-ketoglutarate, AMP, ADP, glyceraldehyde-3-phosphate, 3-phosphoglycerate, 2-phosphoglycerate, dihydroxyacetone phosphate, glucose 1-phosphate, glucose 6-phosphate, oxaloacetate, fructose 6-phosphate, fructose 1,6-bisphosphate) were tested for their influence on the catalytic activity of the enzyme at half-saturating concentrations of ATP and pyruvate.

\section{Pyruvate:Phosphate Dikinase}

For monitoring PPDK activity in the anabolic direction (PEP formation), the discontinuous assay described for PEPS containing $100 \mathrm{mM}$ Tris $/ \mathrm{HCl}, \mathrm{pH} 7.0$ (55 or $70^{\circ} \mathrm{C}$ ), $20 \mathrm{mM}$ $\beta$-mercaptoethanol, $6 \mathrm{mM}$ pyruvate, $15 \mathrm{mM}$ ATP, $10 \mathrm{mM} \mathrm{MgCl}_{2}$ and additional $5 \mathrm{mM} \mathrm{KP}$ was used. Pyruvate formation by PPDK (catabolic direction) was determined either at $70^{\circ} \mathrm{C}$ using a discontinuous assay or at $55^{\circ} \mathrm{C}$ in a continuous assay. In both cases, standard assays were performed in $100 \mathrm{mM}$ Tris/ $\mathrm{HCl}, \mathrm{pH}$ $7.0\left(55\right.$ or $70^{\circ} \mathrm{C}$ ) in the presence of $3 \mathrm{mM}$ PEP, $5 \mathrm{mM}$ AMP and $4 \mathrm{mM} \mathrm{Mg-EDTA}$. The reaction was started by addition of $1 \mathrm{mM} \mathrm{PP}$. In the continuous assay, the reaction mixture additionally contained $0.8 \mathrm{mM} \mathrm{NADH}$ and $10 \mathrm{U} \mathrm{LDH}$, and pyruvate formation was followed directly by the decrease in absorption at $366 \mathrm{~nm}\left[\in 55^{\circ} \mathrm{C}=3.33 \mathrm{mM}^{-1} \mathrm{~cm}^{-1}\right.$ (Fabry and Hensel, 1987)]. At $70^{\circ} \mathrm{C}$ a discontinuous assay was used and the amount of pyruvate formed by PPDK after 20-120 s (sample volume $25-50 \mu \mathrm{L}$ ) was determined at RT in $500 \mu \mathrm{L}$ total volume, $100 \mathrm{mM}$ Tris/HCl (pH 7.0), $0.8 \mathrm{mM} \mathrm{NADH}$ using $10 \mathrm{U} \mathrm{LDH}$ as auxiliary enzyme.

\section{RESULTS}

Archaea utilize modifications of the classical metabolic pathways which are often characterized by novel enzymes with different regulatory properties. The regulation in dependence of the offered carbon source and the switch between glycolytic and gluconeogenic growth is so far only scarcely addressed. Here we identify and characterized the enzymes involved in PEP-pyruvate conversion in Sul. solfataricus.

\section{Pyruvate Kinase}

The open reading frame (ORF) SSO0981 is annotated as PK in the Sul. solfataricus genome and was cloned into the vector pET324. The enzyme was expressed heterologously in E. coli using the pET expression system. The protein was purified by heat precipitation $\left(20 \mathrm{~min} 90^{\circ} \mathrm{C}\right.$ ) and ion exchange chromatography (elution at $360 \mathrm{mM} \mathrm{NaCl}$ ). PK exhibits a molecular mass of approximately $50 \mathrm{kDa}$ (Figure 1A), which matches the calculated molecular mass of $49.8 \mathrm{kDa}$. The total yield of protein was $3 \mathrm{mg}$ out of $9.5 \mathrm{~g}$ of cells (wet weight).

For the ORF SSO0981 PK activity could be confirmed and the enzyme was characterized at $50,65,70$, and $80^{\circ} \mathrm{C}$ (Table 1 ). The Sul. solfataricus PK follows classical Michaelis-Menten kinetics for PEP (0-6 mM) and ADP (0-6 mM) at the different temperatures tested (Figure 2 and Supplementary Figure 1).

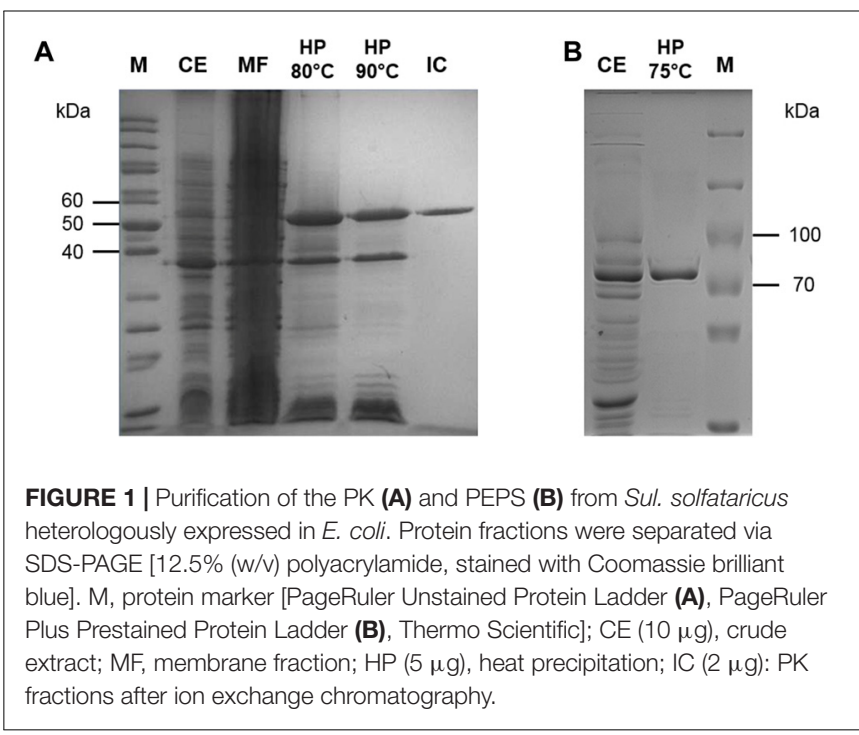


TABLE 1 | Kinetic parameters of the Sul. solfataricus PK for PEP and ADP determined at $50,65,70$, and $80^{\circ} \mathrm{C}$.

\begin{tabular}{lccccc}
\hline Substrate & $\begin{array}{c}\text { Temp } \\
{\left[{ }^{\circ} \mathbf{C}\right]}\end{array}$ & $\begin{array}{c}\boldsymbol{V}_{\mathbf{m a x}} \\
{[\mathbf{U} / \mathbf{m g}]}\end{array}$ & $\begin{array}{c}\boldsymbol{K}_{\text {cat }} \\
{\left[\mathbf{s}^{-\mathbf{1}}\right]}\end{array}$ & $\begin{array}{c}\boldsymbol{K}_{\mathbf{m}} \\
{[\mathbf{m M}]}\end{array}$ & $\begin{array}{c}\boldsymbol{K}_{\mathbf{c a t}} / \boldsymbol{K}_{\mathbf{m}} \\
{\left[\mathbf{m M}^{-\mathbf{1}} \mathbf{s}^{-\mathbf{1}}\right]}\end{array}$ \\
\hline PEP & 50 & 47.9 & 39.7 & 0.23 & 137.3 \\
& 65 & 60.4 & 50.1 & 0.12 & 435.8 \\
& 70 & 70.4 & 58.4 & 0.09 & 628.0 \\
ADP & 80 & 88.7 & 73.0 & 0.26 & 281.0 \\
& 50 & 48.3 & 40.1 & 0.16 & 244.3 \\
& 65 & 63.7 & 52.9 & 0.14 & 385.8 \\
& 70 & 70.8 & 58.8 & 0.07 & 851.9 \\
& 80 & 96.7 & 80.3 & 0.11 & 710.5 \\
\hline
\end{tabular}

For the final enzyme characterization one enzyme preparation was used and the enzyme assays were performed in triplicates. The mean values and standard deviation is shown in Figure 2 and Supplementary Figures 1, 3.

Only for PEP concentrations below $1 \mathrm{mM}$ at $80^{\circ} \mathrm{C}$ a slight deviation was observed. For PEP, the specific activity $\left(V_{\max }\right)$ increased with temperature, with the highest specific activity at $80^{\circ} \mathrm{C}$ with $88.7 \mathrm{U} / \mathrm{mg}$. The determined affinity for PEP $\left(K_{\mathrm{m}}\right.$-values) increased from $0.23 \mathrm{mM}$ at $50^{\circ} \mathrm{C}$ to 0.12 at $65^{\circ} \mathrm{C}$ and $0.09 \mathrm{mM}$ at $70^{\circ} \mathrm{C}$. Only at $80^{\circ} \mathrm{C}$ a decrease in affinity ( $K_{\mathrm{m}}$-value $0.26 \mathrm{mM}$ ) was observed. Therefore, the highest catalytic efficiency was determined at $70^{\circ} \mathrm{C}\left(628.0 \mathrm{mM}^{-1} \mathrm{~s}^{-1}\right)$ with a 2.2 -fold reduction at $80^{\circ} \mathrm{C}\left(281.0 \mathrm{mM}^{-1} \mathrm{~s}^{1}\right)$. The catalytic efficiency for the co-substrate $\mathrm{ADP}$ showed a similar trend with $244.3 \mathrm{mM}^{-1} \mathrm{~s}^{-1}$ at $50^{\circ} \mathrm{C}, 385.8 \mathrm{mM}^{-1} \mathrm{~s}^{-1}$ at $65^{\circ} \mathrm{C}$, $851.9 \mathrm{mM}^{-1} \mathrm{~s}^{-1}$ at $70^{\circ} \mathrm{C}$ and $710.5 \mathrm{mM}^{-1} \mathrm{~s}^{-1}$ at $80^{\circ} \mathrm{C}$ (Table 1). These observed differences in catalytic efficiency are mainly due to the changes of $K_{\mathrm{m}}$-values at the different temperatures.

Numerous metabolites and signaling compounds (fully listed in material and methods) were tested as effectors of Sul. solfataricus PK activity at half-saturating concentration of PEP and ADP. No activator was identified, but ATP and isocitrate acted as inhibitors (Supplementary Figure 2). The product inhibition by ATP and isocitrate was studied in more detail: Approximately $0.8 \mathrm{mM}$ of ATP or isocitrate was required for $50 \%$ inhibition (50\% residual activity) at $60^{\circ} \mathrm{C}$. The inhibition could not be reversed by the addition of PEP or ADP. Additionally, well known activators of classical bacterial and eukaryotic PKs, i.e., AMP and FBP were tested as possible effectors, but showed no effect and did not reverse the inhibition of ATP.
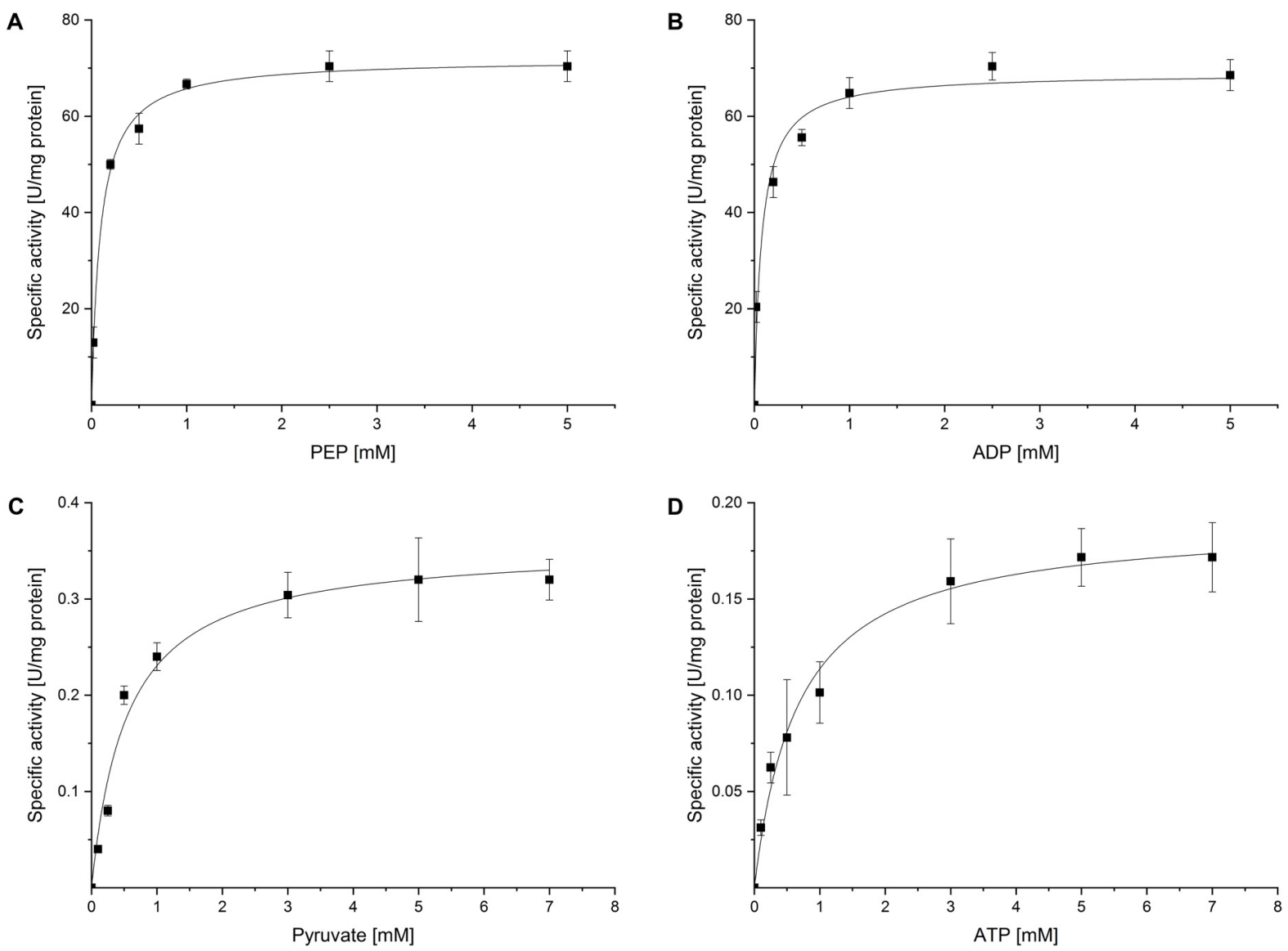

FIGURE 2 | Characterization of PK and PEPS from Sul. solfataricus at $70^{\circ} \mathrm{C}$. PK activity with PEP (A) and ADP (B) and PEPS activity with pyruvate (C) and ATP (D) was determined. Both enzymes follow classical Michaelis-Menten kinetics at $70^{\circ} \mathrm{C}$. All measurements were performed in triplicate, the points in the figures are the mean values and the error bars indicate the standard deviation. Kinetic parameters are given in Tables 1, 2. 


\section{Phosphoenolpyruvate Synthetase (PEPS)}

The ORF SSO0883 is annotated as PEPS in the Sul. solfataricus genome. The encoding gene was synthesized with codon optimization for expression into E. coli using the pET expression system (vector pET11c). The enzyme was partially purified by heat precipitation $\left(20 \mathrm{~min}\right.$ at $\left.75^{\circ} \mathrm{C}\right)$. PEPS exhibits a molecular mass of $89-92 \mathrm{kDa}$ (Figure 1B), which matches approximately the calculated molecular mass of $89.3 \mathrm{kDa}$. Due to its instability no further purification steps were applied and aliquots of the enzyme were directly stored at $-80^{\circ} \mathrm{C}$ in the presence of $20 \%(\mathrm{v} / \mathrm{v})$ glycerol.

The recombinant PEPS from Sul. solfataricus (SSO0883) was shown to catalyze the ATP-dependent formation of PEP. PEPS activity was assayed in the anabolic direction following PEP formation in a discontinuous assay at 65,70 , and $80^{\circ} \mathrm{C}$. The enzyme follows classical Michaelis-Menten kinetics for pyruvate and ATP (Figure 2 and Supplementary Figure 3). Further analysis revealed that in agreement with the classical PEPS reaction AMP and Pi rather than ADP is formed in the anabolic direction. Kinetic properties could not be determined at $80^{\circ} \mathrm{C}$ properly, which might be due to the heat instability of PEPS. The $V_{\max }$-value at $70^{\circ} \mathrm{C}$ is slightly increased and the $K_{\mathrm{m}}-$ value decreased resulting in a higher catalytic efficiency at $70^{\circ} \mathrm{C}$ compared to $65^{\circ} \mathrm{C}\left(0.75 \mathrm{mM}^{-1} \mathrm{~s}^{-1}\right.$ at $65^{\circ} \mathrm{C}$ and $1.04 \mathrm{mM}^{-1} \mathrm{~s}^{-1}$ at $70^{\circ} \mathrm{C}$, respectively, Table 2 ). In the catabolic direction, PEPS activity was determined as $0.032 \mathrm{U} / \mathrm{mg}$ at $70^{\circ} \mathrm{C}$ using PEP, AMP and $\mathrm{P}_{\mathrm{i}}$ as substrates, which is $10 \%$ of its anabolic activity under comparable assay conditions (data not shown). No enzyme activity was detected in the catabolic direction using ADP as phosphate acceptor.

As shown in Supplementary Figure 4, PEPS activity was inhibited by $\alpha$-ketoglutarate and AMP (around $80 \%$ residual activity in presence of $1 \mathrm{mM}$ inhibitor). All other metabolites tested (fully listed in Section "Material and Methods") showed no effect on PEPS activity.

\section{Phosphoenolpyruvate Synthetase (PEPS) or Pyruvate:Phosphate Dikinase (PPDK)}

The predicted PEPS/PPDK (SSO2820, PpsA-2) was cloned into pET11c. The protein was expressed in E. coli and purified by heat precipitation $\left(20 \mathrm{~min}\right.$ at $\left.80^{\circ} \mathrm{C}\right)$ to confirm the respective enzyme

TABLE 2 | Kinetic parameters of Sul. solfataricus PEPS for pyruvate and ATP determined at 65 and $70^{\circ} \mathrm{C}$, respectively.

\begin{tabular}{lccccc}
\hline Substrate & $\begin{array}{c}\text { Temp } \\
{\left[{ }^{\circ} \mathbf{C}\right]}\end{array}$ & $\begin{array}{c}\boldsymbol{V}_{\text {max }} \\
{[\mathbf{U} / \mathbf{m g}]}\end{array}$ & $\begin{array}{c}\boldsymbol{K}_{\text {cat }} \\
{\left[\mathbf{s}^{-1}\right]}\end{array}$ & $\begin{array}{c}\boldsymbol{K}_{\mathbf{m}} \\
{[\mathbf{m M}]}\end{array}$ & $\begin{array}{c}\mathbf{K}_{\text {cat }} / \mathbf{K}_{\mathbf{m}} \\
{\left[\mathbf{m M}^{-1} \mathbf{s}^{-1}\right]}\end{array}$ \\
\hline Pyruvate & 65 & 0.27 & 0.41 & 0.54 & 0.75 \\
& 70 & 0.32 & 0.48 & 0.46 & 1.04 \\
ATP & 65 & 0.17 & 0.25 & 0.47 & 0.53 \\
& 70 & 0.22 & 0.33 & 0.61 & 0.53 \\
PEP + AMP & 70 & 0.03 & 0.05 & ND & ND
\end{tabular}

For the final enzyme characterization one enzyme preparation was used and the enzyme assays were performed in triplicates. The mean values and standard deviation is shown in Figure 2 and Supplementary Figures 1, 3. ND, not determined. activity. For the predicted PPDK (SSO2820) no interconversion of PEP and pyruvate could be detected under different test conditions (PPDK, PK, and PEPS assay), demonstrating that the protein encoded by SSO2820 exhibits neither PPDK, PEPS, nor PK activity (data not shown).

\section{DISCUSSION}

A general feature of all (hyper)thermophilic Archaea analyzed hitherto is the lack of classical bacterial or eukaryotic control points at the beginning and end of the EMP pathway (for review see Bräsen et al., 2014). The archaeal ATP-dependent hexokinase, ADP-dependent glucokinase, ATP-, ADP-, and $\mathrm{PP}_{\mathrm{i}^{-}}$ dependent PFKs lack allosteric properties and also the archaeal PKs typically exhibit reduced, if at all any, regulatory potential. In Sul. solfataricus three candidate genes were annotated for PEPpyruvate conversion, i.e., PK, PEPS and PEPS/PPDK, which were recombinant expressed in E. coli and the corresponding proteins were characterized for their enzymatic and regulatory properties.

\section{Pyruvate Kinase}

Pyruvate kinase catalyzes the final step in glycolysis, the conversion of PEP to pyruvate with the concomitant synthesis of ATP via substrate-level phosphorylation (Reynard et al., 1961). For the ORF SSO0981 annotated as PK the respective activity was confirmed. The enzyme like other PKs requires magnesium or other divalent metal ions for activity (SusanResiga and Nowak, 2004). However, as reported previously for other archaeal PKs, with the exception of the Thermoplasma acidophilum enzyme, the enzyme does not require monovalent cations such as $\mathrm{K}^{+}$or $\mathrm{NH}_{4}{ }^{+}$for activity as described for many other PKs from Bacteria and Eukaryotes (Schramm et al., 2000; Oria-Hernández et al., 2005; Bräsen et al., 2014). The characterization of the Sul. solfataricus $\mathrm{PK}$ at temperatures from $50^{\circ} \mathrm{C}$ to $80^{\circ} \mathrm{C}$ revealed highest catalytic efficiency at $70^{\circ} \mathrm{C}$ (Table 1 and Supplementary Figure 1). No positive cooperativity for PEP or ADP was observed at the different temperatures but effector studies revealed a significant non-competitive inhibition of the Sul. solfataricus PK by ATP and isocitrate $\left(K_{\mathrm{i}}=0.8 \mathrm{mM}\right)$. The addition of (co) substrate or activators of classical bacterial and eukaryotic PKs (i.e., AMP and FBP) did not affect the inhibition of the Sul. solfataricus PK. Therefore the energy charge of the cell (ATP) as well as the availability of building blocks for biosynthesis in the citric acid cycle (isocitrate) seem to play important roles in the regulation of glycolysis in Sul. solfataricus.

To date, only a few PKs from the archaeal domain have been biochemically characterized, i.e., of the hyperthermophiles Thermoproteus tenax (Schramm et al., 2000), Pyrobaculum aerophilum (Solomons et al., 2013), Aeropyrum pernix and Archaeoglobus fulgidus (Johnsen et al., 2003) as well as the moderate thermoacidophile Tpl. acidophilum (Potter and Fothergill-Gilmore, 1992). For most of the archaeal PKs positive cooperativity toward PEP or ADP or for the Tpt. tenax PK toward PEP and $\mathrm{Mg}^{2+}$ was reported. In general, archaeal PKs exhibit no allosteric regulation by classical effectors of bacterial and eukaryotic PKs such as fructose 
1,6-bisphosphate (F1,6BP), fructose 2,6-bisphosphate (F2,6BP), AMP or other sugar phosphates (Siebers and Schönheit, 2005). Only the Tpl. acidophilum PK was shown to be activated by AMP (Potter and Fothergill-Gilmore, 1992). For the PK of Pyb. aerophilum 3-phosphoglycerate (3-PG) was identified as unusual activator (Solomons et al., 2013). Inhibition by ATP was so far only reported for the Arc. fulgidus PK, which, however, could be reversed by higher PEP and ADP concentrations, suggesting a competitive inhibition (Johnsen et al., 2003). Notably, the PK from the hyperthermophilic bacterium Thermotoga maritima exhibits conventional bacterial regulatory properties demonstrating that the differences found for archaeal PKs represent no general adaptation to high temperature (Johnsen et al., 2003).

\section{PEPS/PPDK}

The ORFs SSO2820 and SSO0883 are annotated as PEPS/PPDK and PEPS, respectively. In the lower shunt of the EMP pathway, these enzymes catalyze the interconversion of pyruvate and PEP. PEPS is a member of the PEP-utilizing enzyme family, which also comprises PPDK. PEPS activity was demonstrated for many bacterial and few archaeal species (e.g., Cooper and Kornberg, 1965; Hutchins et al., 2001; Tjaden et al., 2006). Deletion mutant experiments in Escherichia coli and Salmonella typhimurium revealed that the enzyme is crucial for growth on C3 substrates like pyruvate, lactate and alanine (Cooper and Kornberg, 1967; Smyer and Jeter, 1989). In accordance with this gluconeogenic function, for the archaeon Methanothermobacter thermoautotrophicus an essential role for autotrophic growth in the presence of $\mathrm{CO}_{2}$ (Eyzaguirre et al., 1982) and for Pyrococcus furiosus on pyruvate (Schäfer and Schönheit, 1993) was demonstrated.

However, the sequence of SSO2820 does not match the typical size of characterized PEPSs and PPDKs (Figure 3). The protein comprises only the conserved PPDK_N superfamily domain (pfam01326, amino acid location 31-340) involved in PEP/Pyruvate binding. The additional histidine domain (pfam00391, PEP-utilizing enzyme, mobile domain; cl00215, Aconitase swivel domain, amino acid location 353-461) and the nucleotide domain (pfam02896 PEP-utilizing enzyme, TIM barrel domain; cl21481, malate synthase; amino acid location 479-784) characteristic for PEPSs and PPDKs are missing (Herzberg et al., 1996; Lim et al., 2007) (Figure 3).
Both ORFs were heterologously expressed in E. coli and analyzed. Only the three-domain protein SSO0883 exhibited reversible PEPS activity, while the truncated SSO2820 showed neither PEPS nor PPDK (or PK) activity. Notably, SSO2820 was identified as one of the differentially phosphorylated proteins in a previous phosphoproteome study in Sul. solfataricus (Esser et al., 2012; Esser et al., 2016). The protein was phosphorylated under glucose but not under tryptone growth conditions suggesting a so far unknown function in the carbon switch, may be a role in the regulation of PK or PEPS or the PEP-pyruvate conversion.

For the PEPS (SSO0883) gluconeogenic and glycolytic activity with $\mathrm{PEP}, \mathrm{AMP} / \mathrm{P}_{\mathrm{i}}$ (PEPS activity) could be detected although the gluconeogenic direction was clearly preferred. The highest catalytic efficiency in the anabolic direction was observed at $70^{\circ} \mathrm{C}\left(1.04 \mathrm{mM}^{-1} \mathrm{~s}^{-1}\right.$ at $\left.70^{\circ} \mathrm{C}\right)$. For the PEPS from Pyr. furiosus also reversible PEPS activity with a clear preference for the gluconeogenic direction for PEP formation was reported (Hutchins et al., 2001). Also for the PEPSs from Mba. thermautotrophicus and Tpt. tenax an in vivo anabolic function was confirmed (Eyzaguirre et al., 1982; Tjaden et al., 2006). Like for the Sul. solfataricus PEPS (inhibition by AMP and $\alpha$-ketoglutarate, $80 \%$ residual activity in presence of $1 \mathrm{mM}$ inhibitor) also for the Tpt. tenax PEPS allosteric regulation [i.e., inhibition by $\alpha$-ketoglutarate, AMP and ADP $\left(K_{\mathrm{i}}\right.$ of $0.6,0.5$ and $2.6 \mathrm{mM}$, respectively)] was shown. The authors proposed an inhibition by low energy charge of the cell and a linkage of the EMP pathway to amino acid biosynthesis (Tjaden et al., 2006).

Therefore the PEPS (SSO0883) of Sul. solfataricus is a unidirectional anabolic enzyme that is inhibited by low energy charge of the cell (i.e., AMP) and $\alpha$-ketoglutarate, an intermediate of the citric acid cycle. The ORF SSO0883 annotated as PEPS/PPDK is only a truncated protein and possesses neither PEPS or PPDK activity and a possible function in the regulation of PEP-pyruvate conversion is predicted.

\section{Current Insights Into the Regulation of the Carbon Switch in Sul. solfataricus}

Sulfolobus solfataricus misses a functional PFK and therefore the branched ED pathway with ATP-dependent KDG kinase ( $s p E D)$ and glycerate kinase (npED) is used for glycolysis (Ahmed et al., 2005). In addition, the ATP-dependent hexokinase provides sugar phosphates for the generation of pentoses (reverse ribulose

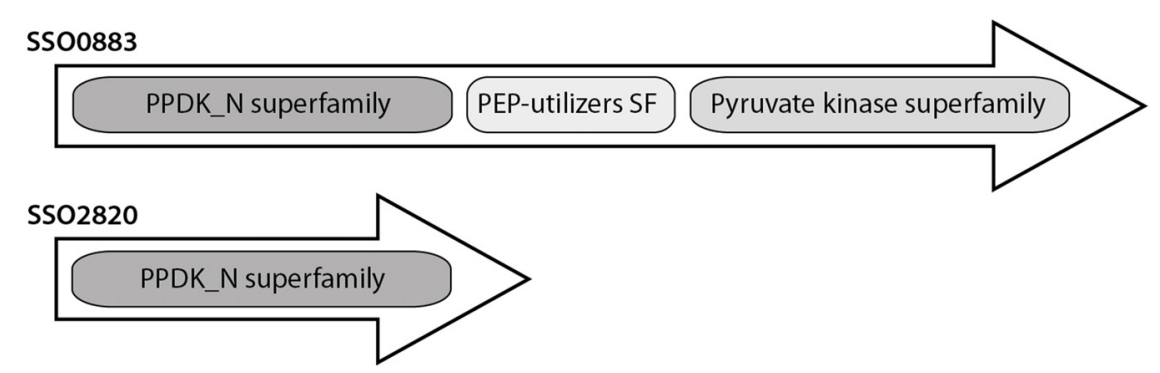

FIGURE 3 | Conserved domain organization of the PEPS and putative PEPS/PPDK from Sul. solfataricus. 
monophosphate pathway), glycogen and trehalose (Nishimasu et al., 2006; Kouril et al., 2013b).

In Sul. solfataricus and other (hyper)thermophiles with optimal growth at $80^{\circ} \mathrm{C}$ a major control site in the EMP/spED pathway was identified at the level of triosephosphate conversion, which has been discussed in respect to metabolic thermoadaptation (Kouril et al., 2013a; Bräsen et al., 2014). Triosephosphates are especially instable at high temperatures [half-lives: GAP $12.4 \mathrm{~min}$ at $70^{\circ} \mathrm{C}, \mathrm{DHAP} 30.8 \mathrm{~min}$ at $70^{\circ} \mathrm{C}$, and 1,3-bisphosphoglycerate (BPG) $1.6 \mathrm{~min}$ at $60^{\circ} \mathrm{C}$ (Kouril et al., 2013a)] and for DHAP and GAP the formation of highly toxic methylglyoxal is reported (Gauss et al., 2014). Due to this metabolic burden, the accumulation of thermolabile triosephosphates seem to be critical for (hyper)thermophiles and a sophisticated regulation to avoid their accumulation in the cell is required: (i) Glyceraldehyde 3-phosphate (GAP)

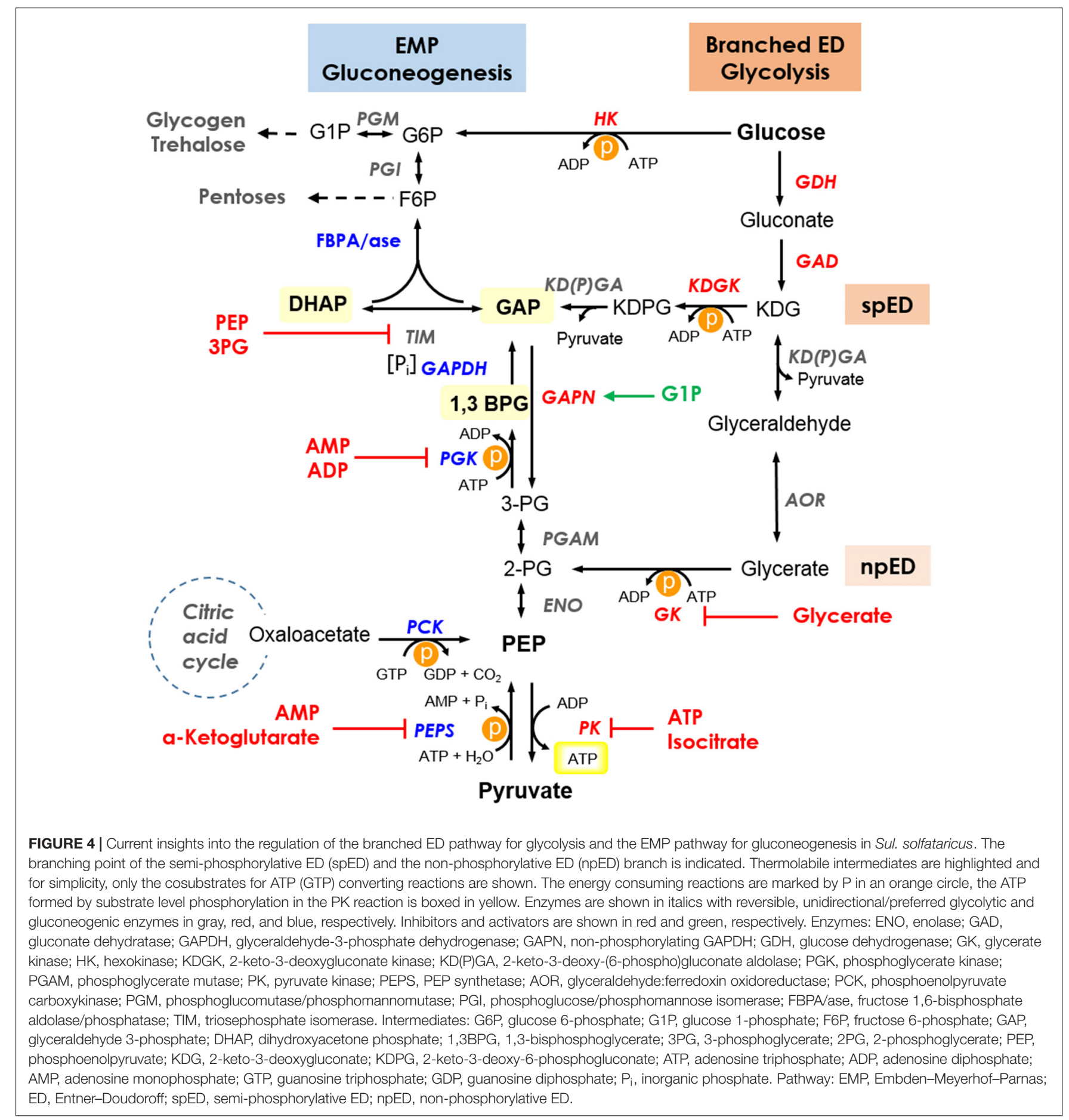


conversion is exerted by the solely gluconeogenic enzyme couple GAPDH and PGK and the catabolic, non-phosphorylating $\mathrm{NAD}(\mathrm{P})^{+}$-dependent GAPDH $(\mathrm{GAPN})$. GAPN catalyzes the direct oxidation of GAP to 3-phosphoglycerate omitting substrate level phosphorylation and is typically activated by G1P, an intermediate in polymer degradation/glycogen metabolism. The glycolytic activity of the GAPDH is hampered by a tremendously high $K_{\mathrm{m}}$-value for $\mathrm{P}_{\mathrm{i}}(409 \mathrm{mM})$ and the PGK, although it prefers the catabolic reaction, is inhibited by low energy charge of the cell $\left[K_{\mathrm{i}}(\mathrm{ADP})=1.14 \mathrm{mM}\right]$ (Kouril et al., 2013a). (ii) The TIM for GAP and DHAP interconversion possesses an anabolic/gluconeogenic function in Sul. solfataricus and is inhibited by $\operatorname{PEP}\left(K_{\mathrm{i}}=0.66 \mathrm{mM}\right)$ and 3-phosphoglycerate $\left(K_{\mathrm{i}}=0.4 \mathrm{mM}\right)$, which might allow fine-tuning of metabolism by redirecting the carbon flux in the glycolytic direction (Kouril et al., 2013a). (iii) The further conversion of triosephophates in the gluconeogenic direction is catalyzed by a solely anabolic, bifunctional FBP aldolase/FBPase (Say and Fuchs, 2010; Kouril et al., 2013a). (iv) In addition, the inhibition of the glycerate kinase by glycerate $\left(K_{\mathrm{i}}=1 \mathrm{mM}\right)$ was demonstrated and a function as throttle valve in the npED pathway to redirect the carbon flux in the gluconeogenic direction was proposed (Kouril et al., 2013b).

In this study we analyzed PEPS and PK activity in Sul. solfataricus: (i) The unidirectional $\mathrm{PK}$ is only active in the glycolytic direction with a catalytic efficiency of $628.0 \mathrm{mM}^{-1} \mathrm{~s}^{-1}$ (PEP, $70^{\circ} \mathrm{C}$; Table 1 ) and is allosterically regulated (i.e., via ATP and isocitrate), which is a well known regulatory mechanism for bacterial and eukaryotic PKs but seems to be rather unusual in Archaea. (ii) The PEPS clearly prefers the gluconeogenic direction (10-times higher activity) with a catalytic efficiency of $1.04 \mathrm{mM}^{-1} \mathrm{~s}^{-1}$ (pyruvate, $70^{\circ} \mathrm{C}$, Table 2) and is allosterically regulated by AMP and $\alpha$-ketoglutarate.

The determined gluconeogenic activity of PEPS was significantly lower $(0.32 \mathrm{U} / \mathrm{mg})$ than the activity of the glycolytic counterpart PK $(70.4 \mathrm{U} / \mathrm{mg})$ both determined at $70^{\circ} \mathrm{C}$ (Tables 1, 2). However, the inhibition of the Sul. solfataricus PK by ATP (50\% residual activity at $0.8 \mathrm{mM}$ ATP at $70^{\circ} \mathrm{C}$ ) is in line with the relatively high $\mathrm{K}_{\mathrm{m}}$ for ATP of the Sul. solfataricus PEPS $\left(0.61 \mathrm{mM}\right.$ at $\left.70^{\circ} \mathrm{C}\right)$. Therefore, high energy charge of the cell and availability of building blocks (i.e., isocitrate) will slow down the glycolytic reaction of the $\mathrm{PK}$ and trigger the gluconeogenic reaction of PEPS. In contrast, low energy charge of the cell

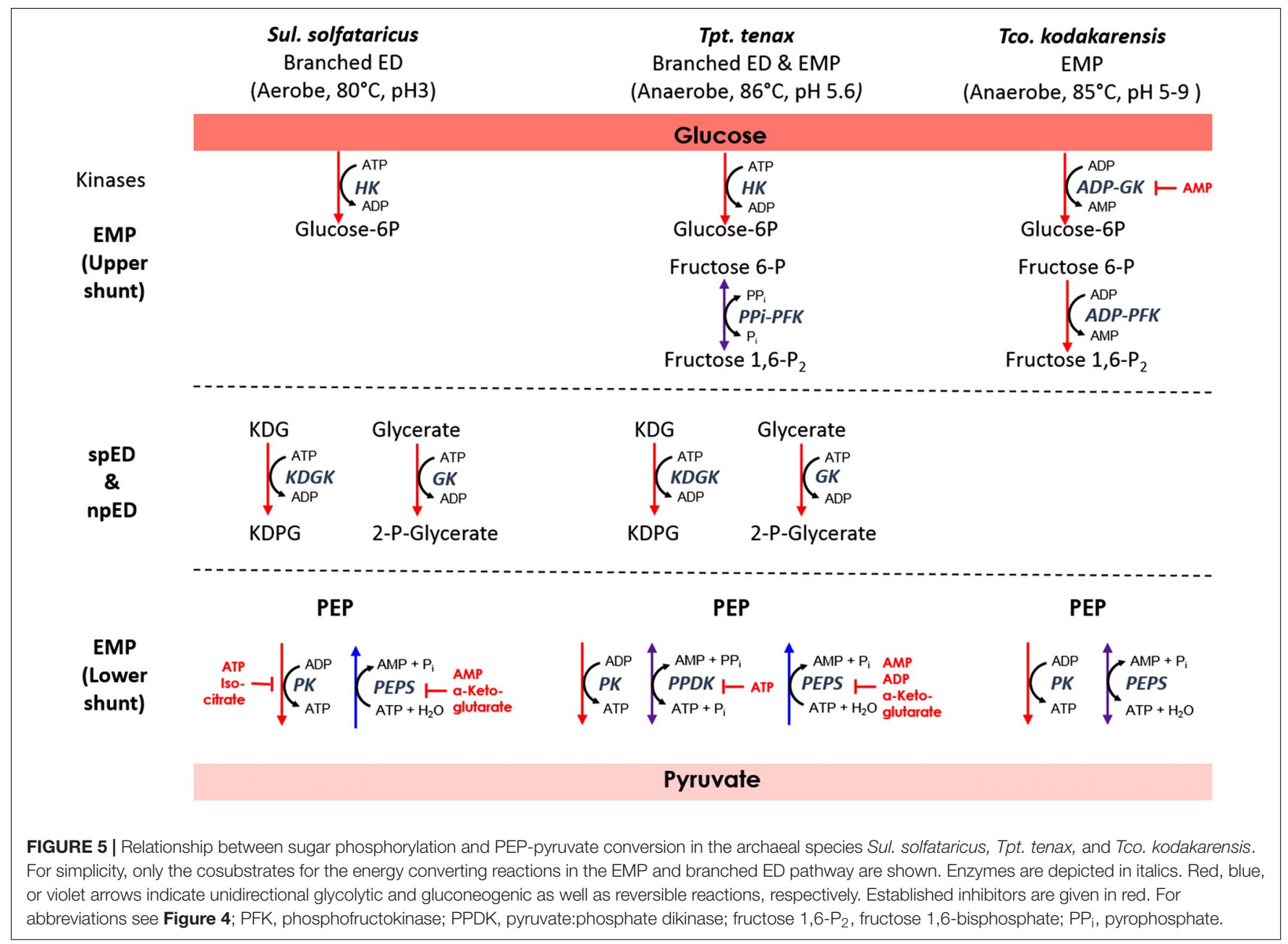


(AMP) and the availability of building blocks in the citric acid cycle for amino acid synthesis ( $\alpha$-ketoglutarate, carbon/nitrogen balance) will inhibit PEPS activity.

In addition to PEPS, BLAST analyses revealed the presence of an alternative pathway for PEP formation via PEP-carboxykinase (PCK, SSO2537, EC4.1.1.32) in Sul. solfataricus. PCK catalyzes the GTP-dependent conversion of oxaloacetate (citric acid cycle) to PEP and $\mathrm{CO}_{2}$. The enzyme of Tco. kodakarensis (AB167819) has been characterized and showed significant similarity to the PCK from Sul. solfataricus (Fukuda et al., 2004). The PCK of Sul. solfataricus was identified as phosphoprotein suggesting a regulation by post-translational modification (Esser et al., 2012). Therefore, beside PEPS a second gluconeogenic enzyme is available in the cell in order to drive the glycolytic switch. The inhibition of the PK by isocitrate, the precursor in the citric acid cycle for the formation of malate and oxaloacetate via the glyoxylate shunt in Sul. solfataricus (Uhrigshardt et al., 2002) might thus enhance gluconeogenesis by favoring PEP formation via PCK.

Therefore, in Sul. solfataricus the energy charge of the cell seems to play a major regulatory role, which is demonstrated by the inhibition of the anabolic/gluconeogenic enzymes PEPS and PGK by ADP and the inhibition of the catabolic/glycolytic PK by ATP. In addition, the activity of the citric acid cycle and glyoxylate bypass monitored by the availability of intermediates (i.e., isocitrate, $\alpha$-ketoglutarate) seems to have an additional control function.

\section{Comparison to the Regulation of the Carbon Switch in Other Studied Archaea}

In contrast to the aerobe Sul. solfataricus the obligate anaerobic hyperthermophiles Pyr. furiosus and Tco. kodakarensis (Thermococcales) as well as Tpt. tenax use a modified, reversible EMP pathway and only in Tpt. tenax the branched ED pathway is active in parallel (Figure 4) (Ahmed et al., 2004; Zaparty et al., 2008). Also in these hyperthermophiles the conserved control point at the level of triosephosphate conversion is established, however, the anaerobes possess in addition to GAPN a ferredoxin dependent GAP:OR (Mukund and Adams, 1995; Reher et al., 2007; Zaparty et al., 2008).

In the different archaeal species there are differences regarding the interconversion of PEP and pyruvate, which seem to be closely linked to the phosphoryl donor in the preparatory phase of glycolysis via sugar kinases (Figure 5 and Table 3).

\section{Thermoproteus tenax}

Thermoproteus tenax uses three enzymes for PEP/pyruvate conversion: PK, PEPS, and PPDK. PK and PEPS are only unidirectional, whereas the PPDK is bidirectional but more efficient in the glycolytic direction. The PPDK from Tpt. tenax is the only archaeal PPDK that has been characterized so far (Tjaden et al., 2006). The enzyme reaction was shown to be reversible with a slight preference for the catabolic direction (2-fold higher catalytic efficiency for pyruvate than for PEP at $70^{\circ} \mathrm{C}$ ). The PPDK of Tpt. tenax was independent from monovalent cations and allosteric inhibition by ATP $\left(\mathrm{K}_{\mathrm{i}}\right.$ of $\left.0.075 \mathrm{mM}\right)$ was reported. The Tpt. tenax PPDK has been discussed as standby enzyme, which
TABLE 3 | Kinetic parameters of enzymes involved in PEP-pyruvate conversion in the archaeal species Tpt. tenax, Pyr. furiosus and Sul. solfataricus.

\begin{tabular}{|c|c|c|c|c|c|}
\hline Organism & Enzyme & $\begin{array}{c}\text { Assay } \\
\text { Temperature }\end{array}$ & $V_{\max }$ & $K_{\mathrm{m}}$ & Reference \\
\hline \multirow[t]{8}{*}{ Tpt. tenax } & $\begin{array}{l}\text { PEPS } \\
\text { (anabolic) }\end{array}$ & $70^{\circ} \mathrm{C}$ & 0.45 & 0.4 (pyruvate) & $\begin{array}{l}\text { Tjaden } \\
\text { et al., } 2006\end{array}$ \\
\hline & & & & 1.0 (ATP) & \\
\hline & $\begin{array}{l}\text { PEPS } \\
\text { (catabolic) }\end{array}$ & $70^{\circ} \mathrm{C}$ & $\mathrm{No}$ & t detectable & \\
\hline & $\begin{array}{l}\text { PPDK } \\
\text { (anabolic) }\end{array}$ & $70^{\circ} \mathrm{C}$ & 1.1 & 0.8 (pyruvate) & \\
\hline & & & & 8.0 (ATP) & \\
\hline & $\begin{array}{l}\text { PPDK } \\
\text { (catabolic) }\end{array}$ & $55^{\circ} \mathrm{C}$ & 2.5 & 0.5 (PEP) & \\
\hline & & & & $0.02(\mathrm{AMP})$ & \\
\hline & PK & $50^{\circ} \mathrm{C}$ & 46 & 0.7 (PEP) & $\begin{array}{l}\text { Schramm } \\
\text { et al., } 2000\end{array}$ \\
\hline \multirow[t]{4}{*}{ Pyr. furiosus } & $\begin{array}{l}\text { PEPS } \\
\text { (anabolic) }\end{array}$ & $80^{\circ} \mathrm{C}$ & 14.9 & 0.11 (pyruvate) & $\begin{array}{l}\text { Hutchins } \\
\text { et al., } 2001\end{array}$ \\
\hline & & & & 0.39 (ATP) & \\
\hline & $\begin{array}{l}\text { PEPS } \\
\text { (catabolic) }\end{array}$ & $50^{\circ} \mathrm{C}$ & 2.5 & 0.4 (PEP) & \\
\hline & & & & 1.0 (AMP) & \\
\hline \multirow[t]{5}{*}{ Sul. solfataricus } & $\begin{array}{l}\text { PEPS } \\
\text { (anabolic) }\end{array}$ & $70^{\circ} \mathrm{C}$ & 0.32 & 0.46 (pyruvate) & This study \\
\hline & & & & 0.61 (ATP) & \\
\hline & $\begin{array}{l}\text { PEPS } \\
\text { (catabolic) }\end{array}$ & $70^{\circ} \mathrm{C}$ & 0.03 & ND & \\
\hline & PK & $70^{\circ} \mathrm{C}$ & 70.4 & 0.09 & \\
\hline & PPDK & $70^{\circ} \mathrm{C}$ & \multicolumn{2}{|c|}{ Not detectable } & \\
\hline
\end{tabular}

The respective kinetic parameters for $S$. solfataricus were generated in this study (see Tables 1, 2 and Figure 2) and were retrieved from the literature for Tpt. tenax and Pyr. furiosus as indicated. ND, not determined.

allows for fine tuning of the energy level (Figure 5 and Table 3) (Schramm et al., 2000; Tjaden et al., 2006).

Intriguingly the organism also relies on a reversible $\mathrm{PP}_{\mathrm{i}}$-dependent $\mathrm{PFK}$ for $\mathrm{F} 6 \mathrm{P}$ and fructose 1,6-bisphosphate conversion (Siebers et al., 1998). Thus both enzymes, the $\mathrm{PP}_{\mathrm{i}}$-dependent $\mathrm{PFK}$ as well as the PPDK, are reversible enzymes that rely on $\mathrm{PP}_{\mathrm{i}}$ for the glycolytic and $\mathrm{P}_{\mathrm{i}}$ for the gluconeogenic direction. In addition, a homolog for a vacuolartype $\mathrm{H}^{+}$-translocating pyrophosphatase from $P y b$. aerophilum was identified in Tpt. tenax enabling generation of a proton motive force (e.g., for ATP synthesis) from $\mathrm{PP}_{\mathrm{i}}$ (Drozdowicz et al., 1999; Siebers et al., 2011). $\mathrm{PP}_{\mathrm{i}}$ is often regarded as waste product that has to be removed by cytoplasmic pyrophosphatases in order to drive anabolic processes such as DNA synthesis, however, $\mathrm{PP}_{\mathrm{i}}$ and polyphosphates in general possess manifold functions and are regarded as ancient energy source (Kornberg, 1995). Therefore, in addition to the energy charge of the cell (ATP/ADP and AMP ratio), that regulates PEPS and PPDK, the $\mathrm{PP}_{\mathrm{i}} / \mathrm{P}_{\mathrm{i}}$ ratio in the cell seems to be another important control point for the glycolytic switch in Tpt. tenax.

\section{Thermococcus kodakarensis}

The level of PEP-pyruvate conversion as a control point is also well established in Tco. kodakarensis (Imanaka et al., 2006). 
In Tco. kodakarensis and Pyr. furiosus a functional PK and a bidirectional PEPS were described (Hutchins et al., 2001; Imanaka et al., 2006) (Table 3). Notably, a genetic analysis (pps deletion strain) in Tco. kodakarensis showed that the PEPS in contrast to $\mathrm{PK}$ is indispensable for glycolysis and has only an additional, although not essential function for gluconeogenesis. The pps deletion strain displayed no growth on maltooligosaccharides and reduced growth on pyruvate (Imanaka et al., 2006). The sugar phosphorylation in the preparatory part of the EMP pahtway in Tco. kodakarensis and Pyr. furiosus is catalyzed by unusal ADP-dependent glucokinases and PFKs. Therefore, it was discussed that the ADP will be consumed by the sugar kinases, which will compete with the $\mathrm{PK}$ for $\mathrm{ADP}$, and thus $\mathrm{PK}$ activity would be lowered and the glycolytic flux reduced (Imanaka et al., 2006). In contrast to PK, PEPS utilizes AMP formed via the ADP-dependent sugar kinase, thus accelerating carbon flux. Thus at high energy/ADP charge of the cell a possible function of $\mathrm{PK}$ in conjunction with adenylate kinase (AMP + ATP $\leftrightarrow 2 \mathrm{ADP}$ ) as valve to maintain the intracellular ADP concentration was proposed (Imanaka et al., 2006). In addition, the competitive inhibition of the ADP-dependent glucokinase from Pyr. furiosus by AMP (approximately $K_{\mathrm{i}}$ value $0.06 \mathrm{mM}$ ) was reported (Verhees et al., 2002). Therefore the utilization of ADP in the sugar kinase reactions in conjunction with the catabolic PEPS reaction in Thermococcales, which reutilizes the formed AMP, seems to represent an important control mechanims to enable an increased glycolytic flux.

\section{CONCLUSION}

The detailed study of the regulation of the lower shunt of glycolysis in Sul. solfataricus in comparison to other archaea reveals different strategies for regulation at the level of PEPpyruvate conversion. However, as well known for bacteria and eukaryotes it seems to be an important regulation point also in archaeal metabolism. Notably, in the Archaea studied so far there seems to be a close link between the sugar kinases and their phosphoryl donors used in the preparatory phase and the utilized

\section{REFERENCES}

Ahmed, H., Ettema, T. J., Tjaden, B., Geerling, A. C., van der Oost, J., and Siebers, B. (2005). The semi-phosphorylative entner-doudoroff pathway in hyperthermophilic archaea: a re-evaluation. Biochem. J. 390(Pt 2), 529-540. doi: 10.1042/bj20041711

Ahmed, H., Tjaden, B., Hensel, R., and Siebers, B. (2004). Embden-meyerhofparnas and entner-doudoroff pathways in Thermoproteus tenax: metabolic parallelism or specific adaptation? Biochem. Soc. Trans. 32, 303-304. doi: 10. 1042/bst0320303

Bräsen, C., Esser, D., Rauch, B., and Siebers, B. (2014). Carbohydrate metabolism in archaea: current insights into unusual enzymes and pathways and their regulation. Microbiol. Mol. Biol. Rev. 78, 89-175. doi: 10.1128/mmbr.00041-13

Cooper, R. A., and Kornberg, H. L. (1965). Net formation of phosphoenolpyruvate from pyruvate by Escherichia coli. Biochim. Biophys. Acta 104, 618-620. doi: 10.1016/0304-4165(65)90374-0 enzymes with different regulatory properties at the level of PEPpyruvate conversion. These different regulatory strategies might be seen as a sophisticated coordination of energy consuming and generating reactions in glycolysis and gluconeogenesis in order to optimize the direction of carbon flux and energy yield. The observed diversity and presence of modified pathways with different, unusual enzymes is in line with an autotrophic origin of life and the acquirement of metabolic enzymes via massive horizontal gene transfer by Archaea (Nelson-Sathi et al., 2015). These modified archaeal pathways with unusual enzymes often from different enzyme families required novel regulatory mechanisms that are adapted to the respective enzyme repertoire and metabolic challenges such as instability of metabolites at high temperature (Bräsen et al., 2014).

\section{AUTHOR CONTRIBUTIONS}

PH, BT, LS, and TK performed the experiments. TK and LS wrote the manuscript, which was edited by $\mathrm{CB}$ and BS. CB and BS conceived the study. All authors approved the final manuscript.

\section{FUNDING}

BS acknowledges the funding by the Federal Ministry of Education and Research (BMBF). PH and TK received funds within the SysMO initiative SulfoSYS (0315004A), TK within the e:biol initiative SulfoSYS ${ }^{\text {BIOTEC }}$ (0316188A) and LS within the e:bio3 initiative HotSySAPP (03120078A). BT received financial support within the HotZyme project from the European Union 7th Framework Program FP7/2007-2013 (Grant Agreement No. 265933). We acknowledge support by the Open Access Publication Fund of the University of Duisburg-Essen.

\section{SUPPLEMENTARY MATERIAL}

The Supplementary Material for this article can be found online at: https://www.frontiersin.org/articles/10.3389/fmicb. 2019.00757/full\#supplementary-material

Cooper, R. A., and Kornberg, H. L. (1967). The direct synthesis of phosphoenolpyruvate from pyruvate by Escherichia coli. Proc. R. Soc. Lond. B Biol. Sci. 168, 263-280. doi: 10.1098/rspb.1967.0065

Drozdowicz, Y. M., Lu, Y. P., Patel, V., Fitz-Gibbon, S., Miller, J. H., and Rea, P. A. (1999). A thermostable vacuolar-type membrane pyrophosphatase from the archaeon Pyrobaculum aerophilum: implications for the origins of pyrophosphate-energized pumps. FEBS Lett. 460, 505-512. doi: 10.1016/S00145793(99)01404-0

Esser, D., Hoffmann, L., Pham, T. K., Bräsen, C., Qiu, W., Wright, P. C., et al. (2016). Protein phosphorylation and its role in archaeal signal transduction. FEMS Microbiol. Rev. 40, 625-647. doi: 10.1093/femsre/ fuw020

Esser, D., Pham, K. T., Reimann, J., Albers, S.-V., Siebers, B., and Wright, P. C. (2012). Change of carbon source causes dramatic effects in the phosphoproteome of the Archaeon Sulfolobus solfataricus. J. Proteome Res. 11, 48234833. doi: 10.1021/pr300190k 
Evans, H. J., and Wood, H. G. (1968). The mechanism of the pyruvate, phosphate dikinase reaction. Proc. Natl. Acad. Sci. U.S.A. 61, 1448-1453. doi: 10.1073/pnas. 61.4.1448

Eyzaguirre, J., Jansen, K., and Fuchs, G. (1982). Phosphoenolpyruvate synthetase in Methanobacterium thermoautotrophicum. Arch. Microbiol. 132, 67-74. doi: 10.1007/BF00690820

Fabry, S., and Hensel, R. (1987). Purification and characterization of D-glyceraldehyde-3-phosphate dehydrogenase from the thermophilic archaebacterium Methanothermus fervidus. Eur. J. Biochem. 165, 147-155. doi: 10.1111/j.1432-1033.1987.tb11205.x

Flamholz, A., Noor, E., Bar-Even, A., and Milo, R. (2012). eQuilibrator-the biochemical thermodynamics calculator. Nucleic Acids Res. 40, D770-D775. doi: 10.1093/nar/gkr874

Fukuda, W., Fukui, T., Atomi, H., and Imanaka, T. (2004). First characterization of an archaeal GTP-dependent phosphoenolpyruvate carboxykinase from the hyperthermophilic archaeon Thermococcus kodakaraensis KOD1. J. Bacteriol. 186, 4620-4627. doi: 10.1128/jb.186.14.4620-4627.2004

Gauss, D., Schoenenberger, B., and Wohlgemuth, R. (2014). Chemical and enzymatic methodologies for the synthesis of enantiomerically pure glyceraldehyde 3-phosphates. Carbohydr. Res. 389, 18-24. doi: 10.1016/j.carres.2013. 12.023

Herzberg, O., Chen, C. C., Kapadia, G., McGuire, M., Carroll, L. J., Noh, S. J., et al. (1996). Swiveling-domain mechanism for enzymatic phosphotransfer between remote reaction sites. Proc. Natl. Acad. Sci. U.S.A. 93, 2652-2657. doi: $10.1073 /$ pnas.93.7.2652

Hutchins, A. M., Holden, J. F., and Adams, M. W. (2001). Phosphoenolpyruvate synthetase from the hyperthermophilic archaeon Pyrococcus furiosus. J. Bacteriol. 183, 709-715. doi: 10.1128/jb.183.2.709-715.2001

Imanaka, H., Yamatsu, A., Fukui, T., Atomi, H., and Imanaka, T. (2006). Phosphoenolpyruvate synthase plays an essential role for glycolysis in the modified embden-meyerhof pathway in Thermococcus kodakarensis. Mol. Microbiol. 61, 898-909. doi: 10.1111/j.1365-2958.2006.05287.x

Johnsen, U., Hansen, T., and Schönheit, P. (2003). Comparative analysis of pyruvate kinases from the hyperthermophilic archaea Archaeoglobus fulgidus, Aeropyrum pernix, and Pyrobaculum aerophilum and the hyperthermophilic bacterium Thermotoga maritima: unusual regulatory properties in hyperthermophilic archaea. J. Biol. Chem. 278, 25417-25427. doi: $10.1074 /$ jbc.M210288200

König, H., Skorko, R., Zillig, W., and Reiter, W.-D. (1982). Glycogen in thermoacidophilic archaebacteria of the genera Sulfolobus, Thermoproteus, Desulfurococcus and Thermococcus. Arch. Microbiol. 132, 297-303. doi: 10.1007/ bf00413378

Kornberg, A. (1995). Inorganic polyphosphate: toward making a forgotten polymer unforgettable. J. Bacteriol. 177, 491-496. doi: 10.1128/jb.177.3.491-496.1995

Kouril, T., Esser, D., Kort, J., Westerhoff, H. V., Siebers, B., and Snoep, J. L. (2013a). Intermediate instability at high temperature leads to low pathway efficiency for an in vitro reconstituted system of gluconeogenesis in Sulfolobus solfataricus. FEBS J. 280, 4666-4680. doi: 10.1111/febs.12438

Kouril, T., Wieloch, P., Reimann, J., Wagner, M., Zaparty, M., Albers, S. V., et al. (2013b). Unraveling the function of the two entner-doudoroff branches in the thermoacidophilic Crenarchaeon Sulfolobus solfataricus P2. FEBS J. 280, 1126-1138. doi: $10.1111 /$ febs. 12106

Kouril, T., Zaparty, M., Marrero, J., Brinkmann, H., and Siebers, B. (2008). A novel trehalose synthesizing pathway in the hyperthermophilic crenarchaeon Thermoproteus tenax: the unidirectional TreT pathway. Arch. Microbiol. 190, 355-369. doi: 10.1007/s00203-008-0377-3

Lamble, H. J., Heyer, N. I., Bull, S. D., Hough, D. W., and Danson, M. J. (2003). Metabolic pathway promiscuity in the archaeon Sulfolobus solfataricus revealed by studies on glucose dehydrogenase and 2-Keto-3-deoxygluconate aldolase. J. Biol. Chem. 278, 34066-34072. doi: 10.1074/jbc.M305818200

Lim, K., Read, R. J., Chen, C. C. H., Tempczyk, A., Wei, M., Ye, D., et al. (2007). Swiveling domain mechanism in pyruvate phosphate dikinase. Biochemistry 46, 14845-14853. doi: 10.1021/bi701848w

Maruta, K., Mitsuzumi, H., Nakada, T., Kubota, M., Chaen, H., Fukuda, S., et al. (1996). Cloning and sequencing of a cluster of genes encoding novel enzymes of trehalose biosynthesis from thermophilic archaebacterium Sulfolobus acidocaldarius. Biochim. Biophys. Acta 1291, 177-181. doi: 10.1016/ S0304-4165(96)00082-7
Moll, R., and Schäfer, G. (1988). Chemiosmotic H+ cycling across the plasma membrane of the thermoacidophilic archaebacterium Sulfolobus acidocaldarius. FEBS Lett. 232, 359-363. doi: 10.1016/0014-5793(88)80769-5

Mukund, S., and Adams, M. W. W. (1995). Glyceraldehyde-3-phosphate ferredoxin oxidoreductase, a novel tungsten- containing enzyme with a potential glycolytic role in the hyperthermophilic archaeon Pyrococcus furiosus. J. Biol. Chem. 270, 8389-8392. doi: 10.1074/jbc.270.15.8389

Nelson-Sathi, S., Sousa, F. L., Roettger, M., Lozada-Chavez, N., Thiergart, T., Janssen, A., et al. (2015). Origins of major archaeal clades correspond to gene acquisitions from bacteria. Nature 517, 77-80. doi: 10.1038/nature 13805

Nishimasu, H., Fushinobu, S., Shoun, H., and Wakagi, T. (2006). Identification and characterization of an ATP-dependent hexokinase with broad substrate specificity from the hyperthermophilic archaeon Sulfolobus tokodaii. J. Bacteriol. 188, 2014-2019. doi: 10.1128/jb.188.5.2014-2019.2006

Oria-Hernández, J., Cabrera, N., Pérez-Montfort, R., and Ramírez-Silva, L. (2005). Pyruvate kinase revisited: the activating effect of K+. J. Biol. Chem. 280, 37924-37929. doi: 10.1074/jbc.M508490200

Orita, I., Sato, T., Yurimoto, H., Kato, N., Atomi, H., Imanaka, T., et al. (2006). The ribulose monophosphate pathway substitutes for the missing pentose phosphate pathway in the archaeon Thermococcus kodakaraensis. J. Bacteriol. 188, 4698-4704. doi: 10.1128/jb.00492-06

Potter, S., and Fothergill-Gilmore, L. A. (1992). Purification and properties of pyruvate kinase from Thermoplasma acidophilum. FEMS Microbiol. Lett. 73, 235-239. doi: 10.1111/j.1574-6968.1992.tb05324.x

Reher, M., Gebhard, S., and Schönheit, P. (2007). Glyceraldehyde-3-phosphate ferredoxin oxidoreductase (GAPOR) and nonphosphorylating glyceraldehyde3-phosphate dehydrogenase (GAPN), key enzymes of the respective modified Embden-Meyerhof pathways in the hyperthermophilic crenarchaeota Pyrobaculum aerophilum and Aeropyrum pernix. FEMS Microbiol. Lett. 273, 196-205. doi: 10.1111/j.1574-6968.2007.00787.x

Reynard, A. M., Hass, L. F., Jacobsen, D. D., and Boyer, P. D. (1961). The correlation of reaction kinetics and substrate binding with the mechanism of pyruvate kinase. J. Biol. Chem. 236, 2277-2283.

Ronimus, R. S., and Morgan, H. W. (2003). Distribution and phylogenies of enzymes of the embden-meyerhof-parnas pathway from archaea and hyperthermophilic bacteria support a gluconeogenic origin of metabolism. Archaea 1, 199-221. doi: 10.1155/2003/162593

Sato, T., and Atomi, H. (2011). Novel metabolic pathways in Archaea. Curr. Opin. Microbiol. 14, 307-314. doi: 10.1016/j.mib.2011.04.014

Say, R. F., and Fuchs, G. (2010). Fructose 1,6-bisphosphate aldolase/phosphatase may be an ancestral gluconeogenic enzyme. Nature 464, 1077-1081. doi: 10. 1038/nature08884

Schäfer, T., and Schönheit, P. (1993). Gluconeogenesis from pyruvate in the hyperthermophilic archaeon Pyrococcus furiosus: involvement of reactions of the Embden-Meyerhof pathway. Arch. Microbiol. 159, 354-356. doi: 10.1007/ BF00290918

Schramm, A., Siebers, B., Tjaden, B., Brinkmann, H., and Hensel, R. (2000). Pyruvate kinase of the hyperthermophilic crenarchaeote Thermoproteus tenax: physiological role and phylogenetic aspects. J. Bacteriol. 182, 2001-2009. doi: 10.1128/JB.182.7.2001-2009.2000

Siebers, B., Klenk, H. P., and Hensel, R. (1998). PPi-dependent phosphofructokinase from Thermoproteus tenax, an archaeal descendant of an ancient line in phosphofructokinase evolution. J. Bacteriol. 180, 2137-2143.

Siebers, B., and Schönheit, P. (2005). Unusual pathways and enzymes of central carbohydrate metabolism in Archaea. Curr. Opin. Microbiol. 8, 695-705. doi: 10.1016/j.mib.2005.10.014

Siebers, B., Zaparty, M., Raddatz, G., Tjaden, B., Albers, S. V., Bell, S. D., et al. (2011). The complete genome sequence of Thermoproteus tenax: a physiologically versatile member of the Crenarchaeota. PLoS One 6:e24222. doi: 10.1371/journal.pone.0024222

Smyer, J. R., and Jeter, R. M. (1989). Characterization of phosphoenolpyruvate synthase mutants in Salmonella typhimurium. Arch. Microbiol. 153, 26-32. doi: 10.1007/BF00277536

Solomons, J. T. G., Johnsen, U., Schönheit, P., and Davies, C. (2013). 3-Phosphoglycerate is an allosteric activator of pyruvate kinase from the hyperthermophilic archaeon Pyrobaculum aerophilum. Biochemistry 52, 5865-5875. doi: 10.1021/bi400761b 
Susan-Resiga, D., and Nowak, T. (2004). Proton donor in yeast pyruvate kinase: chemical and kinetic properties of the active site thr 298 to cys mutant. Biochemistry 43, 15230-15245. doi: 10.1021/bi049864d

Tjaden, B., Plagens, A., Dorr, C., Siebers, B., and Hensel, R. (2006). Phosphoenolpyruvate synthetase and pyruvate, phosphate dikinase of Thermoproteus tenax: key pieces in the puzzle of archaeal carbohydrate metabolism. Mol. Microbiol. 60, 287-298. doi: 10.1111/j.1365-2958.2006.05098.x

Uhrigshardt, H., Walden, M., John, H., Petersen, A., and Anemüller, S. (2002). Evidence for an operative glyoxylate cycle in the thermoacidophilic crenarchaeon Sulfolobus acidocaldarius. FEBS Lett. 513, 223-229. doi: 10.1016/ S0014-5793(02)02317-7

Verhees, C. H., Kengen, S. W., Tuininga, J. E., Schut, G. J., Adams, M. W., De Vos, W. M., et al. (2003). The unique features of glycolytic pathways in Archaea. Biochem. J. 375(Pt 2), 231-246. doi: 10.1042/bj20021472

Verhees, C. H., Koot, D. G., Ettema, T. J., Dijkema, C., de Vos, W. M., and van der Oost, J. (2002). Biochemical adaptations of two sugar kinases from the hyperthermophilic archaeon Pyrococcus furiosus. Biochem. J. 366( $\mathrm{Pt} \mathrm{1),}$ 121-127. doi: 10.1042/bj20011597

Wolf, J., Stark, H., Fafenrot, K., Albersmeier, A., Pham, T. K., Muller, K. B., et al. (2016). A systems biology approach reveals major metabolic changes in the thermoacidophilic archaeon Sulfolobus solfataricus in response to the carbon source L-fucose versus D-glucose. Mol. Microbiol. 102, 882-908. doi: 10.1111/ mmi.13498
Zaparty, M., and Siebers, B. (2011). "Physiology, Metabolism, and Enzymology of Thermoacidophiles," in Extremophiles Handbook, ed. K. Horikoshi (Tokyo: Springer Japan), 601-639. doi: 10.1007/978-4-431-53898-1_28

Zaparty, M., Tjaden, B., Hensel, R., and Siebers, B. (2008). The central carbohydrate metabolism of the hyperthermophilic crenarchaeote Thermoproteus tenax: pathways and insights into their regulation. Arch. Microbiol. 190, 231-245. doi: 10.1007/s00203-008-0375-5

Zillig, W., Stetter, K. O., and Wunderl, S. (1980). The Sulfolobus-"Caldariella" group: taxonomy on the basis of the structure of DNA-dependent RNA polymerases. Arch. Microbiol. 125, 259-269. doi: 10.1007/BF0044 6886

Conflict of Interest Statement: The authors declare that the research was conducted in the absence of any commercial or financial relationships that could be construed as a potential conflict of interest.

Copyright (C) 2019 Haferkamp, Tjaden, Shen, Bräsen, Kouril and Siebers. This is an open-access article distributed under the terms of the Creative Commons Attribution License (CC BY). The use, distribution or reproduction in other forums is permitted, provided the original author(s) and the copyright owner(s) are credited and that the original publication in this journal is cited, in accordance with accepted academic practice. No use, distribution or reproduction is permitted which does not comply with these terms. 